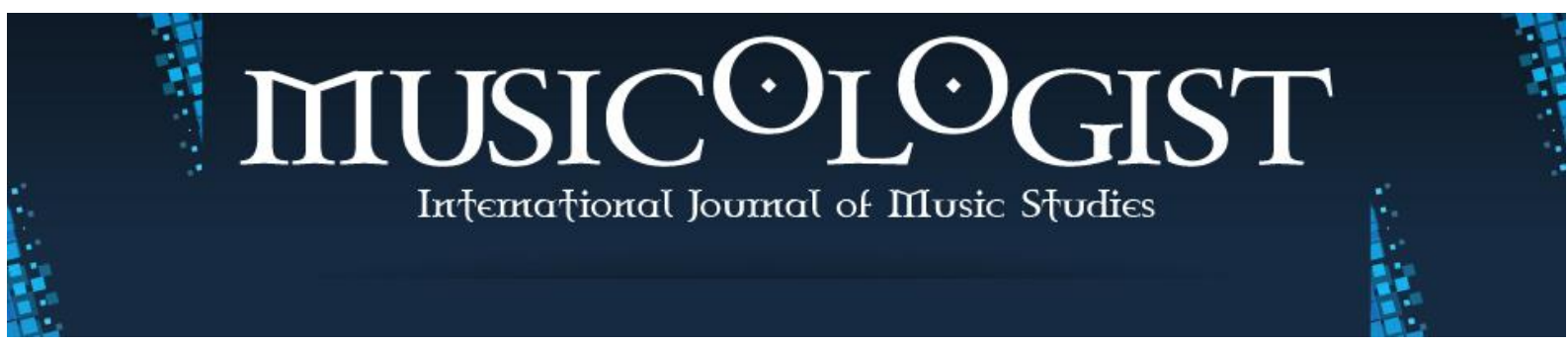

Trabzon University State Conservatory @ $2017-2021$

Volume 5 Issue 2 December 2021

Research Article

Musicologist 2021.5 (2): 166-186

DOI: $10.33906 /$ musicologist.985434

YANNICK WEY

Lucerne University of Applied Sciences and Arts, Switzerland

yannick.wey@hslu.ch

orcid.org/0000-0002-2416-1285

\title{
A Reassessment of Wolfgang Sichardt's 1936 Field Recordings of Swiss Yodel
}

\begin{abstract}
Historical field recordings offer insight both into past performance routines and into the processes and contexts of musical practices in their time. In the wake of renewed interest in musical traditions of the alpine region, I reassessed the magnetic tape recordings created by the Jena University doctoral student Wolfgang Sichardt (1911-2002) from multiple perspectives. The premises and context of the field research in 1936 are reconstructed, in part based on original correspondence; the reception and impact of the research in Germany and Switzerland are assessed; and the exact origin of the recordings is determined wherever possible. Descriptive transcriptions of the entire corpus of yodel and alphorn music visualize the content. The 1936 field recordings, made by Sichardt during a six-week field trip to different areas of Switzerland, document yodels, folk songs, and alphorn melodies on 12 magnetic tape reels, recorded with the latest technology at the time, the $A E G$ Magnetophon $K-2$. Although the results were published afterward (Sichardt, 1939), the magnetic tape recordings remained private until they were donated to the Vienna Phonogram Archive in 2008, and only in the past decade have they been discovered by researchers.
\end{abstract}

KEYWORDS
Yodel
Switzerland
Sound recording
Historical
ethnomusicology
Archive




\section{Introduction}

It is widely accepted that the advent of recording technology led to a new era in music research, because it allowed for the comparison of geographically or chronologically distant musical performances (Lechleitner, 2005; Fargion, 2009; Ziegler and Lechleitner, 2017). The study of recordings and their paraphernalia, such as recording devices, allows for a partial reconstruction of the historical performance, while the surrounding material, such as field notes and letters, helps form a comprehensive picture (Stock, 2001, 2016). As Hebert and McCollum have pointed out, "Historical research often requires careful examination of manuscripts, audio/visual data, and musical instruments or other artifacts, some of which maybe unique and difficult to access" (Hebert and McCollum 2014: 45). In the present case of the field recordings made by the German doctoral student Wolfgang Sichardt (1911-2002), the source material spans a variety of media: the original publications by Sichardt, their published and internal reviews, correspondence letters in preparation for the fieldwork, notations of the recorded melodies by other authors of the same time, and various unpublished reports and notes surrounding Sichardt's 1936 fieldwork. The compilation of these sources would not have been possible without the contribution of the persons listed in the acknowledgments section below.

This article serves as a companion to a corpus of field recordings that can be considered some of the most important for historical ethnomusicology in the European Alps. It offers more context for recent studies that are partly based on Wolfgang Sichardt's research (Wey, 2019, 2020).

Fargion (2009), referring to John Baily, uses the terms "test recording" and "context recording" to distinguish between those made explicitly for the researcher and those made at real live music events. The Sichardt corpus consists entirely of "test recordings" and has to be interpreted accordingly. The musicians represented are those who agreed to have their yodeling recorded, and according to the yodeler and composer Willi Valotti (personal communication, September 03, 2018), many declined to do so. ${ }^{1}$

\footnotetext{
${ }^{1}$ Valotti specifically mentions cases in the Toggenburg region, where some yodelers were unwilling to perform for the purpose of recording.
} 


\section{Wolfgang Sichardt (1911-2002)}

Sichardt was born 18.05.1911 in Weimar. In 1931 he moved to Leipzig to study literature, art history, and piano. From 1934, he studied art history and musicology and in 1937 completed his dissertation at the University of Jena with the title Der Alpenländische Yodel und den Ursprung des Jodelns (Sichardt, 1939).

At the time when I began research on Sichardt's recordings, little was known about Sichardt beyond his dissertation (Sichardt, 1939) and related research (Danckert, 1937a; Sichardt, 1936a, 1937a, 1937/1938, 1949). His publications include the monograph Der alpenländische Jodler from 1939 and a series of short articles in the years 1936 to 1939, some of which he co-authored with his doctoral supervisor Werner Danckert (19001970). From 1934 to 1937 he worked on and completed his dissertation. Due to the high cost of printing the dissertation, Sichardt was unable to publish it until 1939, two years after its completion. For a publisher to print his dissertation, Sichardt had to rely on an expert opinion from Josef Müller-Blattau, a professor of musicology (Müller-Blattau, n.d., ca. 1938). ${ }^{2}$ In 1940 Sichardt was working for the Saarbrücken radio station, the Reichssender Saarbrücken. While his colleagues received the designation 'UK,' which stood for 'unabkömmlich' ('indispensable'), Sichardt was drafted into the army. During his military service, Sichardt fell seriously ill and spent time in a military hospital, but this may have saved his life. In 1945, Sichardt was taken prisoner of war by American troops in Sondershausen (near the city of Weimar) and transferred to Rennes in France. Two years later, after having spent much time in infirmaries due to illnesses, he was released, and returned to Germany. In 1953 he took up a position as a music librarian in Wiesbaden, where he worked until his retirement.

\section{The 1936 fieldwork and the twelve magnetic tapes}

As part of his dissertation project, Sichardt carried out six weeks of field research in Switzerland in September and October 1936. He recorded yodels, folk songs, alphorn tunes, and cattle calls in various German- and French-speaking regions, as well as Rhaetian Switzerland. Among these recordings from various sources and practices are some of the oldest field recordings of alpine yodeling, which differ fundamentally from

\footnotetext{
2 Müller-Blattau, who was a member of the NSDAP and the SA ('Sturmabteilung', 'Storm Detachment'), wrote a generally favorable evaluation, but he criticized the last chapter, titled 'anthropological outlook' [anthropologischer Ausblick], as being superfluous.
} 
the style cultivated for radio and record studio productions at the time. The magnetic tape recordings are highly relevant to the history and reception of yodeling research and transcription - aspects which will be discussed in the following sections.

Sichardt's field research represented a departure from the guidelines for song collections as written during the same period by the musicologist Walter Wiora (1938: 53). Sichardt did not wish to adapt the songs to music-aesthetic conventions or to select only songs that were considered 'valuable'. Instead, his research focused on phenomena that contradicted aesthetic conventions. The intention behind this focus was to prove the existence of "older layers"3 of music (Sichardt, 1936b: 178) that had been preserved over centuries, and to provide evidence thereof in the form of transcriptions. ${ }^{4}$ Consequently, in his transcriptions, Sichardt attempted not to resolve or align deviations from tonal and metrical norms, but rather to further emphasize them.

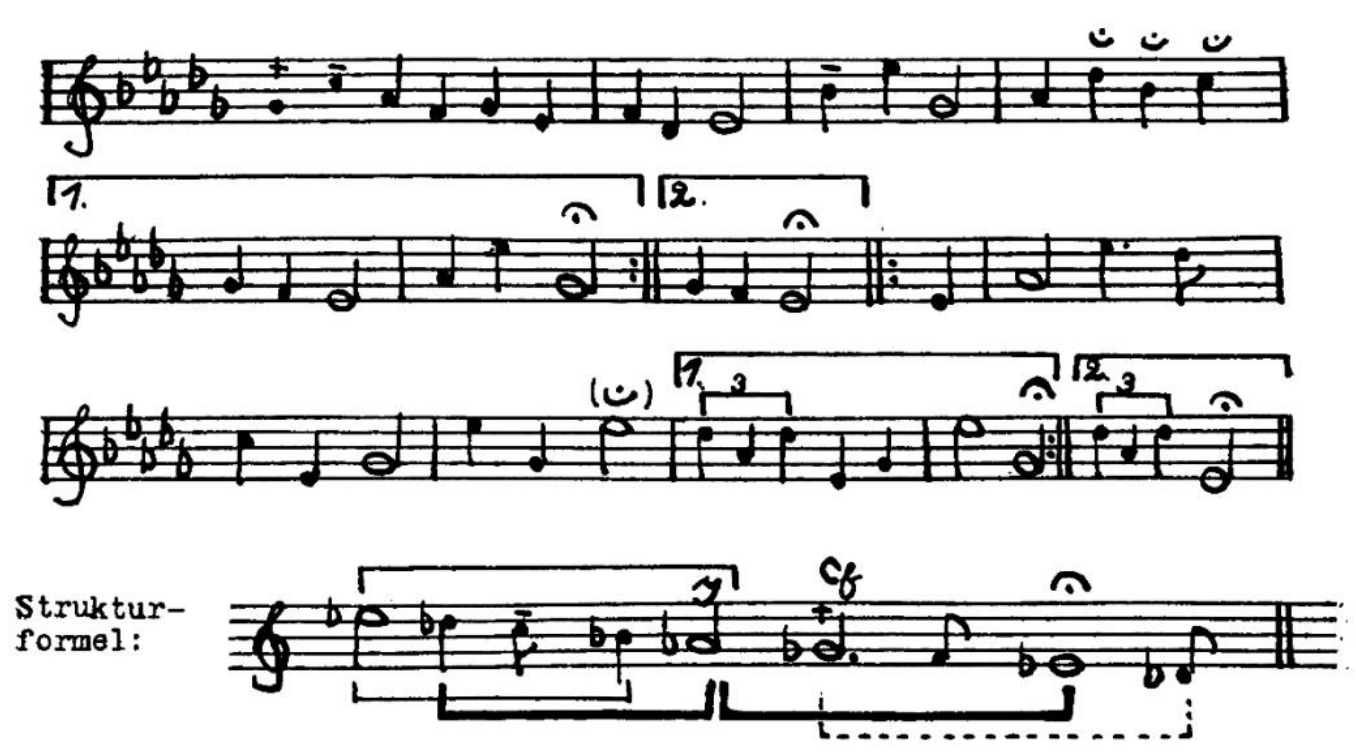

Figure 1. Transcription by Sichardt detailing microtonal and rhythmical deviations. Below the transcription, Sichardt shows a "structure formula", a scale with tetrachordal groups (Sichardt, 1937b: 777).

To carry out this research, the Allgemeine Elektrizitätsgesellschaft or AEG [General Electricity Company] provided Sichardt with the state-of-the-art recording device, the 'Magnetophon K2'. ${ }^{5}$ The goal and the methodological background of the research, as

\footnotetext{
${ }^{3}$ All citations from German sources have been translated by the present author.

${ }^{4}$ Sichardt published detailed transcriptions of his recordings, but not the recordings themselves.

${ }^{5}$ From a letter (see the list of Sichardt's correspondence below) sent August 28, 1936, we learn that the lending of the recording device was helped by the student association 'Fachgruppe Musik der Reichsführung Deutsche Studentenschaft'.
} 
described in Sichardt's publications, was to classify recordings into different strata and to find nothing less than the origin of yodeling. Obvious flaws in this reasoning were already apparent at the time. Sichardt's reasoning took place within the methodological paradigm of 'Kulturkreislehre,' at that time popular in German anthropology (Graebner, 1911; Hornbostel 1925). The methodology of Kulturkreislehre has been largely abandoned since then, which means that the conclusions of the dissertation printed in 1939 are overall no longer considered valid (Wey, 2020). They relied on the transfer of stratigraphic methods from archaeology and geology, which was critically reflected in the American anthropologist Clyde Kluckhohn's 1936 essay, "Some Reflections on the Method and Theory of the Kulturkreislehre." Kluckhohn writes: "The Schichten [strata] concept is clearly geological, and the idea of 'cultural fossils' is clearly an analogy from paleontology" (Kluckhohn, 1936: 166). The Kulturkreislehre remained respected as a theory of cultural evolution in Germany up to the 1960s (Schneider, 1976). To conclude, it offered Sichardt a methodological tool to find answers to his research question: What is the origin of yodeling? Sichardt did not consider the criticism and the apparent flaws of this method. We may assume that his supervisor, Werner Danckert, played an important role in this. Danckert was at the time a proponent of the Kulturkreislehre and argued for its application in musicological research (Danckert, 1937b). Despite these methodological issues, the latest achievements of the time in sound recording technology made it possible to make recordings in remote mountainous areas, even though this was associated with new difficulties. Sichardt was traveling alone, and he was asked not to hand over the device to anyone for possible repair-the AEG apparently wanted to avoid letting competitors study the device. Sichardt emphasized the importance of recording technology innovation for field research. According to his account, the participants were delighted that the recordings could be listened to immediately afterward. However, the fact that the rural communities in Switzerland at the time did not have a comprehensive power supply network made things even more difficult, as Sichardt had to look for recording locations where the necessary voltage was available. On a hand-drawn map, he underlined the villages where recordings took place (Sichardt, 1939: 169): 


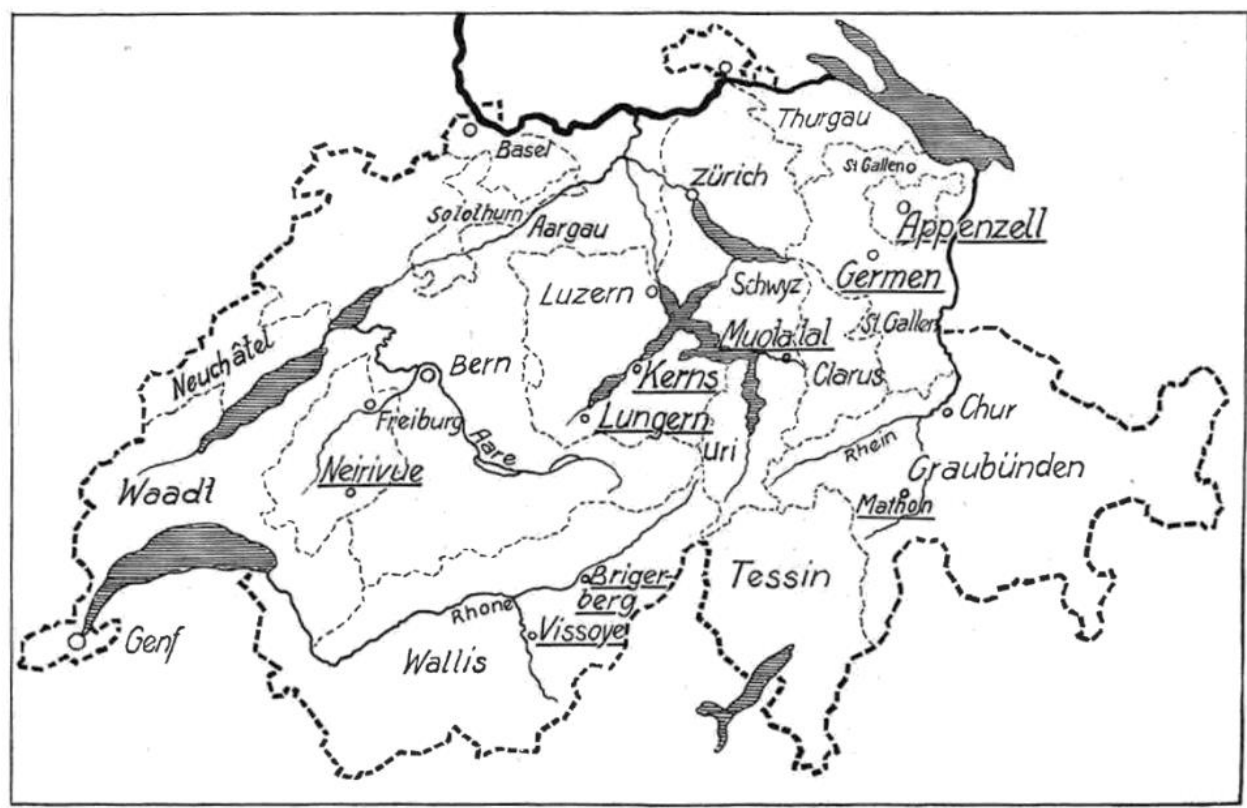

Figure 2. A map drawn by Sichardt (1939: 169) indicates the locations (underlined villages) of the recordings.

The most comprehensive sound documents are those from the recording locations of Appenzell and Muotathal, where Sichardt found particularly 'old' melodies that would be useful for the discussion of the question of the 'origin of yodeling'. In summary, the following recordings are available, distributed over eleven of the twelve magnetic tape reels (the designations for the musical pieces correspond literally to those of the original): 


\begin{tabular}{|c|c|c|}
\hline $\begin{array}{l}\text { Tape } \\
\text { reel }\end{array}$ & Location & Recordings according to Sichardt's (1939:171) terminology \\
\hline 1,2 & Appenzell & $\begin{array}{l}9 \text { solo yodels, } 1 \text { yodel with cattle calls, } 1 \text { Kuhreihen }{ }^{6}, 2 \text { yodel } \\
\text { duets, } 5 \text { alphorn tunes, } 1 \text { alphorn scale, } 2 \text { yodel songs }\end{array}$ \\
\hline 3 & Nesslau & 4 solo yodels, 2 yodel duets \\
\hline 3,4 & Kerns & $\begin{array}{l}5 \text { solo yodels, } 1 \text { Alpine blessing, } 7 \text { three-part yodel, } 3 \text { alphorn } \\
\text { tunes, } 1 \text { alphorn scale }\end{array}$ \\
\hline 4,5 & Lungern & 7 solo yodels, 3 two-part yodels, calls and whoops, 2 yodel songs \\
\hline 6,7 & Muotatal & $\begin{array}{l}11 \text { solo yodels, } 8 \text { yodel duets, } 6 \text { alphorn melodies, } 2 \text { alphorn tunes, } \\
1 \text { alphorn scale, } 2 \text { cattle calls, } 1 \text { Alpine blessing (spoken) }\end{array}$ \\
\hline 7,8 & Mathon & 17 songs, 2 yodel songs, 1 yodel duet \\
\hline 9 & Brigerberg & 5 solo yodels \\
\hline 10 & Vissoie & 1 yodel, 5 songs \\
\hline 10,11 & Neirivue & $\begin{array}{l}1 \text { two-part yodel, } 4 \text { yodel songs, } 1 \text { song with a yodeled refrain, } 1 \\
\text { Ranz des Vaches, }{ }^{8} 1 \text { alphorn tune }\end{array}$ \\
\hline
\end{tabular}

Table 1. Content of eleven of the magnetic tape reels with field recordings.

Each piece is labeled with a letter. On the reels, the individual pieces are thus numbered alphabetically in sequence (1a, 1b, etc.). The list is not quite complete because on reel 7 the letters $\mathrm{E}$ and $\mathrm{F}$ are repeated $(\mathrm{a}, \mathrm{b}, \mathrm{c}, \mathrm{d}, \mathrm{e}, \mathrm{f}, \mathrm{e}, \mathrm{f}, \mathrm{g}, \mathrm{..})$, and these repetitions are not included in the written list.

At the beginning of each recording session, Sichardt blew a pitch pipe tuned to an A at ca. 440 Hertz. This served to document any shifts in pitch due to the speed of the magnetic tape during recording. However, such deviations cannot be detected on any of the eleven tapes. The original pitch pipe, together with the original recordings, is kept in the Vienna Phonogram Archive. The twelfth magnetic tape reel does not contain field recordings, but rather piano music - some of it fragmentary - as well as small bits of conversation. These may have been used as test recordings for handling the magnetophone. At the end,

\footnotetext{
${ }^{6}$ The recording of a 'Kuhreihen', i.e., a kind of traditional herding song documented in $18^{\text {th- }}$ and $19^{\text {th }}$-century travelogues, is in fact a rendition of Heinrich Tobler's (1777-1838) composition 'Appenzeller Sennenlied.' 7 The alpine blessing [Alpsegen] is a shepherd's prayer with which, during the alpine summer, the herdsmen invoke God, Mary, and the saints for protection from danger. All living creatures of an alp, belongings, and property are thus entrusted to a higher care (Senti, 2018).

8 'Ranz des Vaches' is the French name for the above mentioned 'Kuhreihen'. The village where these recordings were made, Neirivue, is located in a French-speaking community in the Canton of Fribourg.
} 
we hear a voice, possibly Sichardt's, reading aloud a letter of recommendation by Wilhelm Altwegg. This and various other letters allow us to reconstruct parts of the 1936 field trip.

\section{Reconstruction of the field trip based on preparatory correspondence and a 1986 interview}

Further details about the plans and preparations for the field trip come from letters between Sichardt and his contacts in Switzerland. All of the letters are from or to Wilhelm Altwegg (1883-1971), who, at that time, was a professor of philology at the University of Basel and the commissioner for the Swiss Folk Song Archive. The letters are listed with summaries of their content in Table 3 in the appendix. Unfortunately, while the digitized versions are available, I was unable to recover the original letters, despite an extensive search among relevant individuals and archives, including Altwegg's estate in the Basel University Library. A further request to the Folk Song Archive showed that the correspondence of the years 1934-1936 includes yellow note slips with the remarks "Sichardt, 12.8.36, removed" or “To Sichardt, 30.8.1936, removed" (Miriam Kull, personal communication, July 13,2021$)$. Thus, the original letters have been transferred without documenting their new location.

The two most important contacts in Switzerland who facilitated Sichardt's research were Altwegg and Karl Meuli (1891-1968), the president of the Swiss Folk Music Society at the time. Both were relatively sympathetic to the project, and both referred Sichardt to Hanns in der Gand, ${ }^{9}$ a well-known folk song collector in Switzerland. On August 12, 1936, Sichardt wrote to Altwegg at the Volksliedarchiv in Basel, asking for assistance in finding contacts in the villages he would be visiting:

In the context of a doctoral thesis at the University of Jena, which deals with Swiss folk music and especially with the yodel, I intend to make recordings of yodels, alphorn melodies, etc., throughout Switzerland in the near future. This undertaking will naturally involve several difficulties. Not least of all, since I am not so well versed in the dialect, it will often be difficult for me to communicate with people. It would therefore be very valuable to me if I could ask teachers, innkeepers, or other persons for a little help in the service of my

\footnotetext{
${ }^{9}$ Hanns in der Gand (1882-1947) was a Swiss folk song collector and researcher. His real name was Ladislaus Krupski but he adopted the name 'Hanns in der Gand' as a pseudonym to simplify contact with the local population.
} 
recording work by means of a letter of recommendation from the Basel Folk Song Archive.

At the time, Hanns In der Gand was entrusted with the task of collecting folk songs. Altwegg emphasized, however, that there was no obligation for In der Gand to offer assistance to the fieldworker. On the same date, Altwegg wrote to In der Gand:

[...] The young German, whom I have never seen in person, had contacted the Volksliedarchiv, and I prompted Ms. Dr. Stöcklin to reply diplomatically that our material was available to him for study only in such a way that no publication rights would be violated to which we were entitled. [...] At the request [...] I [...] first asked for a certificate from his professor, which has now arrived, very good and with the indication that the young man [...] the most splendid recording equipment is at his disposal [...]. And the recordings, I have asked for them for our society's archive. Because we have to grab at such an opportunity - precisely because we do not have such means as Germany can give to its people. But once again, we have no obligations to Mr. S. [...].

This letter also notes that Sichardt had already contacted Karl Meuli, the president of the Swiss Folk Society. In the meantime, according to a letter dated 30 August 1936, a meeting between Sichardt and In der Gand had been planned, although further details of the meeting are not known.

In his letter to Sichardt of August 30, Altwegg expressed interest in the sound recordings and tried to obtain them for the Folk Song Archive. He also mentioned his concern that the copyright of the materials in the Swiss archives be respected. However, Altwegg's intentions to archive the sound recordings in Basel were never realized; the magnetic tapes remained in Sichardt's private possession and were not made available to the public during his lifetime.

We learn more about the circumstances of the 1936 field trip from an interview with the sound engineering expert Friedrich Engel on 11.09.1986 (Engel, 1986). During his fieldwork, Sichardt was traveling in a car, and most of the interior space was taken up by the recording equipment. This included a high-quality microphone. In the interview with Engel, Sichardt spoke about how he found yodelers, the process of recording itself, and the analyses that followed. According to Engel, Sichardt traveled to remote villages, and upon arrival, sought to talk to a teacher or a priest there, who might then point him towards yodelers. He received good leads this way. Then, he visited the yodelers and 
recorded their songs right away (the recordings had to be made immediately, as there were no recurring visits to the same places). The recordings always took place indoors, for example, in a school building. Major technical problems did not occur. There were, however, difficulties with the power supply, which was not always reliable in rural areas.

Engel noted that, after listening to the recordings several times, Sichardt selected a number of melodies that seemed particularly interesting. These were transferred to a record for subsequent musical analysis. The twelve tapes make up the complete collection; if Sichardt had more tapes with him that were not needed, he returned them to AEG. Thus, the field recordings are completely documented.

\section{Contemporaneous reactions in Germany and Switzerland to Sichardt's research publications}

The research was published (Sichardt, 1939) on the eve of the Second World War, and its reception was inevitably colored by the conflict. In the following year, reviews in German and Swiss journals reveal some of the perceptions of this research and the influence of the extraordinary situation. The rejection in Switzerland of a German musicologist's research on Swiss music must be read in the context of the time. In 1940, Germany laid out a plan to invade Switzerland, the so-called 'Unternehmen Tannenbaum' ['operation fir tree'] (Stüssi-Lauterburg, 2003). The plan was dismissed later, but the impression of menace lasted. In this atmosphere, the below-mentioned commentator, Prof. Krupski, described the danger of the Germans using research to develop 'cultural outposts' in Switzerland. In contrast, an early favorable review came out in the German journal Die Musik. Musicologist Wolfgang Boetticher (1939/1940: 20) wrote:

In the present boom of folk-musical considerations, this Jena dissertation will be of particular interest, because here for the first time the attempt is made to summarize the yodel problem, which has already been treated in many small contributions and essays, and to provide scientific clarification.

Wolfgang Boetticher (1914-2002), who received his doctorate in 1939 with a dissertation on Robert Schumann, became that same year the head of the music policy liaison office within the Third Reich's 'Amt Rosenberg,' the office for cultural and surveillance policy, headed by Alfred Rosenberg. While Sichardt's book was well received by Boetticher, it was criticized in Switzerland. Reference has already been made to a 
critical review in the Swiss Archives of Folklore, which highlighted deficiencies in content. Its author (signed only with the initials 'R.-I.') sums up:

Thus, the whole treatise is to be used with some caution, but we are grateful to the author for having once unrolled the whole problem and for having done useful preliminary work in some respects. The last word about yodeling, however, should not be spoken with this writing. (R.-I. 1944: 111)

While this review makes a factual criticism based on ambiguities in content, politically motivated rejections due to the times can be traced in other reviews, based on unpublished sources; such a sharp criticism can be found in a letter dated July 20,1943, from the estate of the composer and yodel enthusiast Heinrich Leuthold (1910-2001) (Staatsarchiv Nidwalden P 137/5), signed by "Prof. Dr. A. Krupski" and addressed to a pharmacist named "E. Wydler." Krupski was apparently returning a borrowed copy of Sichardt's 'Der alpenländische Jodler,' and wrote:

Dear Mr. Wydler!

In the enclosure, you will receive Vol. II [of the series Schriften zur Volksliedkunde und völkerkundlichen Musikwissenschaft] Wolfgang Sichardt 'Der alpenländische Jodler' back. My brother and I don't think much of the book, just like your uncle, who is a music professor. It is a German phenomenon, as such just come out now and are supported by the German government. Bridgeheads in foreign countries, at first seeming harmless and yet dangerous and intended for very specific purposes. In the meantime, history will ruthlessly judge this so-called science [...]

With best regards,

Prof. Dr. A. Krupski. (Krupski, 1943, StANW P 137/5)

\section{Tracing the recordings: The cases of the Brigerberg and the Lungern tapes}

For each sound recording, Sichardt listed the place, in many cases the name of the performer, and in some cases, also the profession, in the appendix to his 1939 book. Information about the melodies, however, is missing. To find out whether these are wellknown melodies and whether they still belong to the repertoire of local yodeling clubs today, the recordings were played and submitted to connoisseurs from the respective regions. The results from all regions would go beyond the scope of this paper and were partly published elsewhere (for Muotatal see Wey, 2020; for Appenzell see Wey, 2019). 
The examples presented here refer to two regions: the canton of Valais and Central Switzerland.

Brigerberg is located in the southwest of Switzerland, situated in a mountain valley (see figure 2). At least two of the recordings from the Brigerberg tape (magnetic tape 9) are transcribed in a booklet (see example notations below), most likely written by Theodul Erpen, a teacher in Ried-Brig. His son Karl Erpen $\left({ }^{*} 1935\right)$ co-founded the yodel club "Zer Tafernu" in Ried-Brig and passed the music booklet on to the yodel composer Ewald Muther, to whom we owe this information (Ewald Muther, personal communication January 19, 2018). The two transcribed yodels are labeled in Sichardt's recordings as Der Brigerbärger, designated "Solo Yodel 9I," and Der Gampischer, "Solo Yodel 9K". The name of the solo yodeler, Johann Eyer, is not identified by Erpen in the booklet, but appears as "Hans Eyer, of Wendelin" in the minute book of the Yodel Club 'Immergrün' [Evergreen]. In the music booklet, below the transcription of Der Brigerbärger, Erpen wrote: "6. Febr[uary] 1939 notated." Thus, it dates from only a few years after the recording. There are no other remarks in the booklet that would offer more insights into the origin of the transcription. In the left upper corner Erpen writes "langsam" [slow], but in the recording the yodeler, Johann Eyer, takes a quick tempo of $84 \mathrm{bpm}$ for the half note or 168 for the quarter. The dotted rhythms notated in the second part, after the repetition, offer a hint that Erpen indeed notated the piece based on a slower tempo: these rhythms are hardly singable at the fast tempo, and Eyer replaces the dotted rhythms with continuous eighth notes in his recording for Sichardt. 


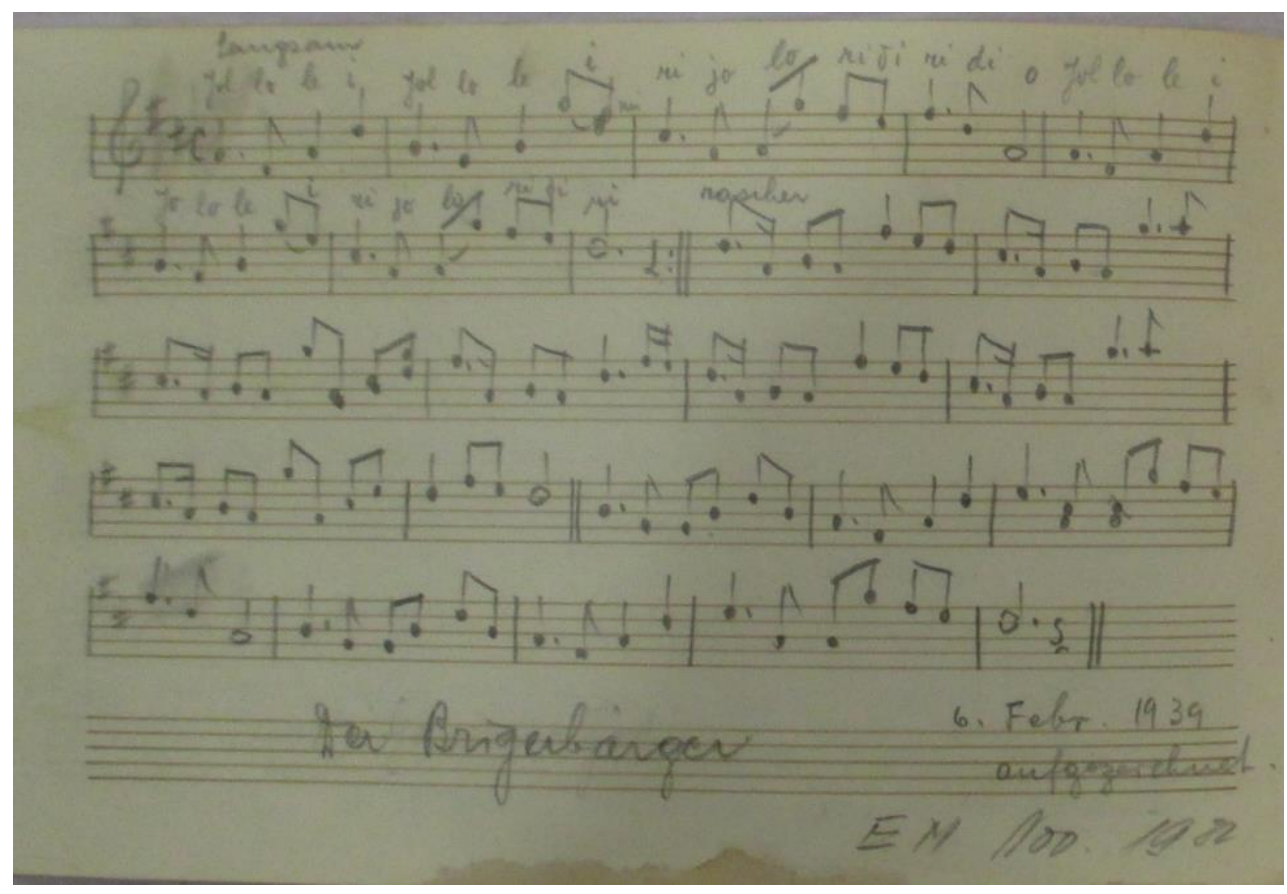

Figure 3. Manuscript of Der Brigerbärger in the notebook of Theodul Erpen (n.d., ca. 1939). The song title is written below the notation.

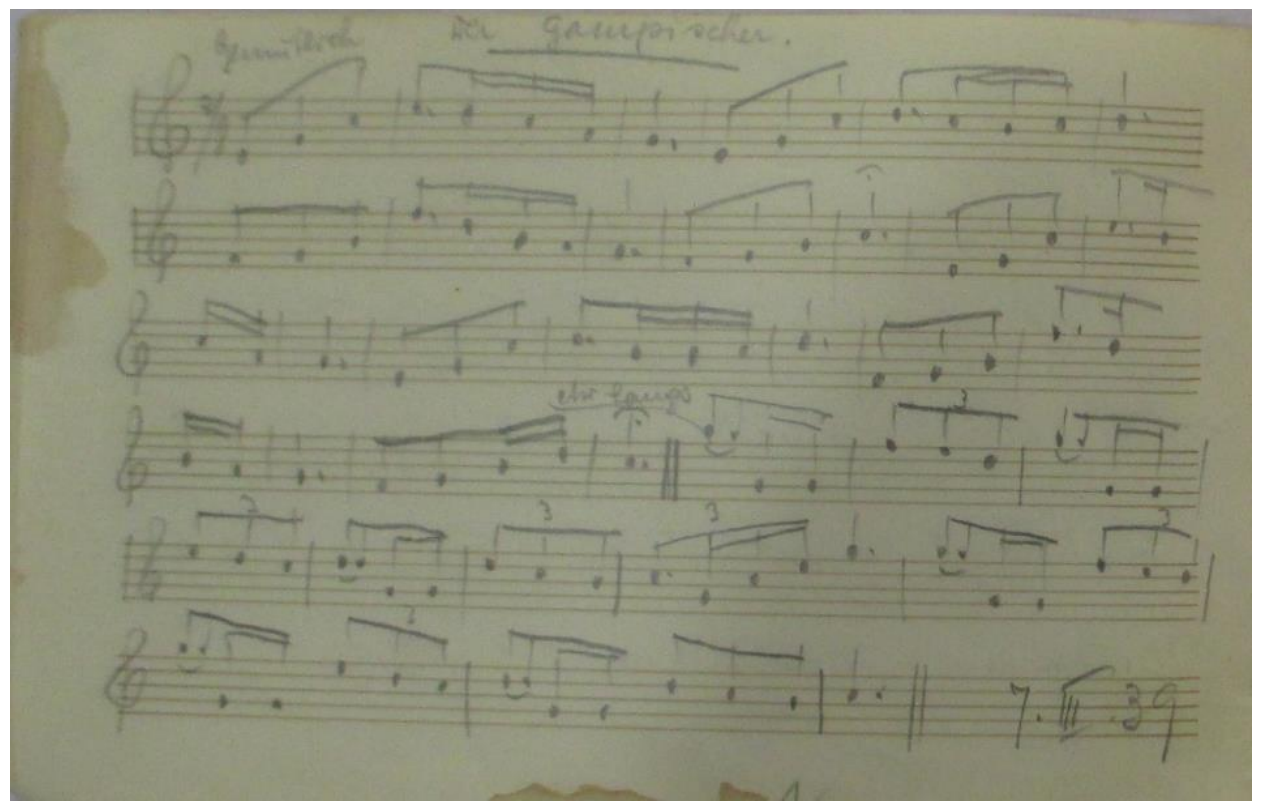

Figure 4. Manuscript of Der Gampischer in the notebook of Theodul Erpen (n.d., ca. 1939).

For the discussion of another set of Sichardt's recordings, the Lungern tapes recorded on the magnetic reels 4 and 5 , we change the location from the south-west of the map of the field recordings Central Switzerland (see figure 2).

Thanks to close listening and comparison with locally known melodies from Lungern, Edi Gasser, an expert on and collector of the regional yodel repertoire, was able to identify several of the melodies on Sichardt's tapes (Gasser, 2014a), and to match these recorded 
melodies to existing notations in Gasser's database (Gasser, 2014b). The latter, a short unpublished manuscript, is an inspiring source for the comparison of past and present interpretations with approximately two generations of oral tradition in between. Table 2 sums up Gasser's attribution of names to the (unnamed) recordings:

\begin{tabular}{lll} 
Track & Location & Name \\
\hline $4 \mathrm{a}$ & Kerns & Obdesseler \\
$4 \mathrm{~b}$ & Kerns & $\begin{array}{l}\text { Landenberger- } \\
\text { Gratjodel }\end{array}$ \\
& & Leewägriabler \\
4c, 4k, 5h & Kerns, Lungern & D'r alt Schorieder \\
$4 \mathrm{~d}$ & Kerns & Stockalper-Jödeli \\
$4 \mathrm{f}$ & Kerns & Schönbiel-Juiz \\
$4 \mathrm{~h}$ & Lungern & S'Mälche \\
$5 \mathrm{a}$ & Lungern & Klewenjuiz \\
$5 \mathrm{c}, 5 \mathrm{f}$ & Lungern & Iwi-Juiz \\
$5 \mathrm{i}$ & Lungern &
\end{tabular}

Table 2. Attribution of names to yodel recordings in Kerns (tape 4) and Lungern (tapes 4 and 5) according to Gasser (2014a).

This connection of Sichardt's untitled recordings to the locally known names was only possible with the local expert knowledge of Gasser. Sichardt did not note any titles or names of yodels, which is legitimate: Yodels, without song texts, are often either not given a name at all, or names are assigned in the small circle of a yodeling club or in a village and differ between locations and groups. In comparison, today, in many cases one name has been established to identify a certain melody. This happened mainly because of CD (and other media) recordings, the printing of a name on a booklet, and the following identification of the melodic structure with the name (Ammann et al. 2021). With these links between contemporary names and historical recordings, we can prove that that a melody has been handed down over the generations since 1936 with changes small enough to still be identified as the same piece of music. Furthermore, a comparison between musical styles of the different period became possible (Gasser, 2014b): Yodel interpretations in the past and today, melody changes over time, interpretive freedoms, and comparisons of yodeling technique. 


\section{Relevance of the recordings and future prospects}

Sichardt's research, although grounded in obsolete methods of interpretation, paved the way for ethnomusicological work in the Alpine region that went beyond the collection and cataloging of folk songs. Research published in the following decades in most cases cited Sichardt's historical recordings (Wiora, 1958) and his cross-comparisons of different musical genres in the Alpine region (Frauchiger, 1941). His publications also served as a springboard for later research, which remained scarce throughout the $20^{\text {th }}$ century-Alpine Europe received little attention from international ethnomusicologists. Important additions, however, include the books by Max Peter Baumann (1976) and Sylvie Bolle-Zemp (1991, 1992). In her "Reflections on the History of Yodeling," Haid $(2005,2006)$ bases her theory partly on Sichardt's hypothesis of different historical layers.

Sichardt intended to find the 'origin of yodel' and classify recordings into different historical layers. In contrast, the present look at this archival material is defined by current research questions, and therefore reassesses the recordings through different approaches. Using computational analysis, we aim to explain the existence of regional tonal systems proposed in the literature, and to understand ways of interpretation as well as regional differences. A comparison of three samples of yodeling from the Muotatal region from three generations, the first of being Sichardt's recordings, has shown a gradual approximation of the tonal scale to the equal tempered tuning (Wey, 2020). Such analysis of historical field recordings will help to correct or complement existing narratives, and the provenance of the preserved music will allow us to trace the transmission and transformation of known yodel and alphorn melodies over the past three generations. In the words of Edi Gasser (2014a), who reconstructed the repertoire recorded in the villages of Kerns and Lungern: "I am especially interested in these recordings to show the difference to today's performance practice, to the interpretation of natural yodels. At that time there were neither notes nor canned sounds. The yodeler sang by ear, he sang the melody as he remembered it approximately and partly 'trimmed' it according to his own ability and feeling." 


\section{Acknowledgments}

Many of the sources discussed in this article were compiled during the research project "Musical Relationship between Alphorn Music and Yodeling - Fact or Ideology?" (Ammann et al. 2019), funded by the Swiss National Science Foundation and led by Raymond Ammann. Edi Gasser and Ewald Muther helped to locate the recordings in their musical traditions and to find other sources such as the Brigerberg notebook. Further sources and information were contributed by Andrea Kammermann (Lucerne School of Music), Thomas Nussbaumer (University Mozarteum Salzburg), Friedrich Engel, and Martina Sichardt (HMT Leipzig).

\section{REFERENCES}

Ammann, Raymond; Kammermann, Andrea and Wey, Yannick. (2019). Alpenstimmung. Musikalische Beziehung zwischen Alphorn und Jodel - Fakt oder Ideologie? [Musical Relationship Between Alphorn Music and Yodeling - Fact or Ideology?]. Zürich: Chronos.

Ammann, Raymond; Kammermann, Andrea; and Wey, Yannick. (2021). Jodeln im Kopf: Musikkognitive Erkenntnisse aus der Alpsteinregion [Findings of a Music Cognitive Study in the Alpstein Region]. Zürich: Chronos.

Boetticher, Wolfgang. (1939/1940). "Wolfgang Sichardt: Der alpenländische Yodel und der Ursprung des Jodelns" [Wolfgang Sichardt: The Alpine Yodel and the Origin of Yodeling]. Review, Die Musik. 32(1): 20.

Bolle-Zemp, Sylvie. (1991). "La voix claire. Conceptions esthétiques et valeurs sociales des chanteurs de la Gruyère (Suisse)" [The Clear Voice. Aesthetic Conceptions and Social Values of the Singers of Gruyère (Switzerland)]. Cahiers d'ethnomusicologie 4: 117-130.

Bolle-Zemp, Sylvie. (1992). Le réenchantement de la montagne. Aspects du folklore musical en Haute-Gruyère [The Re-enchantment of the Mountain. Aspects of Musical Folklore in Haute-Gruyère]. Geneva: Georg.

Danckert, Werner. (1937a) "Die Schallaufnahmen im Dienste neuer Volksliedforschung” [Sound recordings in the service of new folk song research]. Die Musik. 29(4): 282-284. 
Danckert, Werner (1937b). "Musikwissenschaft und Kulturkreislehre” [Musicology and Kulturkreislehre]. Anthropos. 32(1): 1-14.

Engel, Friedrich. (1986). [Interview with Wolfgang Sichardt]. Unpublished audio. 11.09.1986.

Erpen, Theodul. (n.d., ca. 1939). [untitled notebook]. Unpublished manuscript.

Fargion, Janet Topp. (2009). “For My Own Research Purposes'?: Examining Ethnomusicology Field Methods for a Sustainable Music" The World of Music, 51(1): 7593.

Frauchiger, Fritz. (1941). "The Swiss Kuhreihen". The Journal of American Folklore. 54(213/214): 121-131.

Gasser, Edi. (2014a). Infos zu den Aufnahmen von Kerns und Lungern von Musikwissenschaftler Wolfgang Sichardt [Information regarding the recordings in Kerns and Lungern by the musicologist Wolfgang Sichardt]. Unpublished manuscript.

Gasser, Edi. (2014b). Juiz-Interpretationen früher und heute: Melodiewandel im Lauf der Zeit, Interpretations-Freiheiten, Jodel-Technik [Yodel interpretations in the past and today: melody changes over time, interpretive freedoms, yodeling technique]. Unpublished manuscript.

Graebner, Fritz. (1911). Methode der Ethnologie [Method of Ethnology], Heidelberg: C. Winter.

Haid, Gerlinde. (2005). "Yodel from Austria - a Contribution to Early European Polyvocality". The Second International Symposium on Traditional Polyphony,Rusudan Tsurtsumia und Joseph Jordania (Eds.): pp: 23-27. Tbilisi: Tbilisi State Conservatory.

Haid, Gerlinde. (2006). "Überlegungen zur Geschichte des Jodelns" [Reflections on the History of Yodeling]. Histoire des Alpes / Storia delle Alpi / Geschichte der Alpen. 11: 4960.

Hebert, David G. and McCollum, Jonathan. (2014). "Methodologies for historical ethnomusicology in the twenty-first century." Theory and Method in Historical 
Ethnomusicology, Eds. David G. Hebert and Jonathan McCollum: pp. 35-83. Lanham, Maryland: Lexington Books.

Hornbostel, Erich Moritz von. (1925). "Die Entstehung des Jodelns" [The Origin of Yodeling]. Bericht über den Musikwissenschaftlichen Kongress in Basel, Ed. Schweizerische Musikforschende Gesellschaft: pp. 203-210. Leipzig: Breitkopf and Härtel.

Kluckhohn. Clyde. (1936). "Some Reflections on the Method and Theory of the Kulturkreislehre". American Anthropologist. 38(2): 157-196.

Krupski, A. (July 20, 1943). [untitled letter]. Nidwalden State Archive, StANW P 137/5.

Lechleitner, Gerda. (2005). "'Capturing' Sound: The Phonopraph in (Early) Folk Music Research". Traditiones. 34(1): 101-110.

Müller-Blattau, Josef. (n.d., ca. 1938). [Untitled Evaluation of Sichardt's Dissertation]. Unpublished manuscript.

R.-I. (1944). Review of the book, Der alpenländische Jodler und der Ursprung des Jodelns by Wolfgang Sichardt (The Alpine Yodel and the Origin of Yodeling). Schweizerisches Archiv für Volkskunde. 41: 110.

Schneider, Albrecht. (1976). Musikwissenschaft und Kulturkreislehre: zur Methodik und Geschichte der Vergleichenden Musikwissenschaft [Musicology and Kulturkreislehre: On the Methodology and History of Comparative Musicology]. Bonn-Bad Godesberg: Verlag für Systematische Musikwissenschaft.

Senti, Alois. (2018). "Sarganserland alpine blessing”. Living Traditions in Switzerland. Retrieved from https://www.lebendigetraditionen.ch/tradition/en/home/traditions/sarganserland-alpine-blessing.html.

Sichardt, Martina. (2020). Biographisches zu Dr. phil. Wolfgang Sichardt. Unpublished manuscript.

Sichardt, Wolfgang. (1936a). "Alpenländische Volksmusik. Eine Forschungsreise mit dem 'Magnetophon'” [Alpine Folk Music. A Research Expedition with the 'Magnetophon']. Die Musik. 29(3): 177-181. 
Sichardt, Wolfgang. (1936b). "Mit Tonaufnahmegeräten ins Alpengebiet" [With Audio Recording Devices into the Alpine Region]. Die Musikwoche. 4(52): 5-7.

Sichardt, Wolfgang. (1937a). "Altgermanisches Musikgut im alpenländischen Yodel” [Old Germanic Music in Alpine Yodeling]. Allgemeine Musikzeitung. 64: 52-53.

Sichardt, Wolfgang. (1937b). “Alpenländische Volksmusik im Lichte musikethnologischer Forschung." [Alpine folk music in the light of ethnomusicological research], Anthropos 32(5/6): 773-779.

Sichardt, Wolfgang. (1937/1938). "Deutsche Musikstudenten auf der Freusburg: Drittes Reichsmusiklager der Reichsstudentenführung" [German Students of Music at the Freudsburg: Third Reichsmusiklager of the Reichsstudentenführung]. Deutsche Musikkultur. 2(5): 313-315.

Sichardt, Wolfgang. (1939). Der alpenländische Yodel und der Ursprung des Jodelns [Alpine Yodel and the Origin of Yodeling]. Berlin: Hahnefeld.

Sichardt, Wolfgang. (1949). "Gegenwartsfragen der Volksliedforschung” [Contemporary Questions of Folk Music Research]. Neue Musik-Zeitschrift. 3(7): 183-185.

Stock, Jonathan. (2016). "Theory and method in historical ethnomusicology." Ethnomusicology Forum. 25(3): 377-380.

Stock, Jonathan. (2001). "Toward an Ethnomusicology of the Individual, or Biographical Writing in Ethnomusicology", World of Music. 43(1): 5-19.

Stüssi-Lauterburg, Jürg. (2003). “Angriffe und Angriffspläne gegen die Schweiz von 1792 bis 2003" [Attacks and Attack Plans against Switzerland from 1792 to 2003], Allgemeine Schweizerische Militärzeitschrift. 169: 2-19.

Wey, Yannick. (2019). Transkription wortloser Gesänge: Technik und Rückwirkungen der Verschriftlichung des Jodelns und verwandter Gesänge im deutschsprachigen Alpenraum [Transcription of Wordless Songs: Technique and Impact of the Transcription of Yodeling and Related Songs in the German-speaking Alpine Region]. Innsbruck: Innsbruck University Press. Retrieved from http://dx.doi.org/10.15203/3187-81-8. 
Wey, Yannick. (2020). "Transformations of Tonality: A Longitudinal Study of Yodeling in the Muotatal Valley, Central Switzerland." Analytical Approaches to World Music. 8(1): 144-163. Retrieved from

http://www.aawmjournal.com/articles/2020a/Wey AAWM Vol 8 1.html.

Wiora, Walter. (1938). "Die Aufzeichnung und Herausgabe von Volksliedweisen" [The recording and publishing of folk songs]. Jahrbuch für Volksliedforschung 6 (1938): 53-93.

Wiora, Walter. (1939). "Die Tonarten im deutschen Volkslied” [The Scales in German Folk Song]. Deutsche Musikkultur. 3(6): 428-440.

Wiora, Walter. (1958). “Jodeln” Musik in Geschichte und Gegenwart. 7: 73-79.

Ziegler, Susanne and Lechleitner, Gerda (Eds.). (2017). Historical Sources of Ethnomusicology in Contemporary Debate. Cambridge: Cambridge Scholars Publishing. 


\section{Appendix: Letters from and to Wilhelm Altwegg}

\begin{tabular}{|c|c|c|c|c|}
\hline No. & sender & recipient & date & Content summary \\
\hline 1 & $\begin{array}{l}\text { Wolfgang } \\
\text { Sichardt }\end{array}$ & $\begin{array}{l}\text { Wilhelm } \\
\text { Altwegg }\end{array}$ & 12.08.1936 & $\begin{array}{l}\text { Sichardt explains his plans and asks for } \\
\text { a letter of recommendation by the } \\
\text { Swiss Folk Song Archive to facilitate his } \\
\text { exchange with locals. He emphasizes } \\
\text { the proximity of his travel and hence } \\
\text { asks for a swift reply. }\end{array}$ \\
\hline 2 & $\begin{array}{l}\text { Werner } \\
\text { Danckert }\end{array}$ & $\begin{array}{l}\text { Wolfgang } \\
\text { Sichardt }\end{array}$ & 15.08.1936 & $\begin{array}{l}\text { Attestation of Sichardt's work as a } \\
\text { doctoral candidate and description of } \\
\text { the planned field work, to record } \\
\text { "stylistic particularities" } \\
\text { [Stilbesonderheiten] with the help of } \\
\text { high-quality technology }\end{array}$ \\
\hline 3 & $\begin{array}{l}\text { Wolfgang } \\
\text { Sichardt }\end{array}$ & $\begin{array}{l}\text { Wilhelm } \\
\text { Altwegg }\end{array}$ & 28.08.1936 & $\begin{array}{l}\text { Sichardt writes again to Altwegg and } \\
\text { includes the attestation letter from his } \\
\text { supervisor Danckert. }\end{array}$ \\
\hline 4 & $\begin{array}{l}\text { Wilhelm } \\
\text { Altwegg }\end{array}$ & $\begin{array}{l}\text { Wolfgang } \\
\text { Sichardt }\end{array}$ & 30.08 .1936 & $\begin{array}{l}\text { Altwegg sends a letter of } \\
\text { recommendation. He suggests that } \\
\text { Sichardt contact "Prof. Meuli" in Basel } \\
\text { [the philologist Karl Meuli (1891- } \\
\text { 1968)], as well as Hanns In der Gand. } \\
\text { Altwegg expresses the interest of his } \\
\text { institution in buying copies of the } \\
\text { recordings. }\end{array}$ \\
\hline 5 & $\begin{array}{l}\text { Wilhelm } \\
\text { Altwegg }\end{array}$ & $\begin{array}{l}\text { Wolfgang } \\
\text { Sichardt }\end{array}$ & 30.08 .1936 & $\begin{array}{l}\text { A letter of recommendation mentioning } \\
\text { the quality of the recording device and } \\
\text { a call to those who might be able to help } \\
\text { Sichardt with his research. }\end{array}$ \\
\hline 6 & $\begin{array}{l}\text { Wilhelm } \\
\text { Altwegg }\end{array}$ & $\begin{array}{l}\text { Hanns In } \\
\text { der Gand }\end{array}$ & 30.08 .1936 & $\begin{array}{l}\text { Altwegg states that Meuli forwarded a } \\
\text { letter from Sichardt to him, and that he } \\
\text { assigned Dr. Stoecklin [the } \\
\text { ethnographer Adèle Stoecklin, (1876- } \\
\text { 1960)] to respond to Sichardt. He goes } \\
\text { on to say that he first requested an } \\
\text { attestation by Sichardt's professor } \\
\text { [Danckert] and that in the course of a } \\
\text { possible collaboration copyrights } \\
\text { should not be infringed. }\end{array}$ \\
\hline
\end{tabular}

Table 3. Correspondence between Sichardt and representatives of Swiss folk music institutions and private persons in preparation for the 1936 field trip. 